\title{
Corporate Legitimacy and Advertising: British Companies and the Rhetoric of Development in West Africa, 1950-1970
}

\begin{abstract}
Development, modernity, and industrialization became dominant themes in corporate advertising in Africa in the 1950s and remained prevalent through the following two decades while many African nations were gaining independence. British businesses operating there created a publicity strategy that couched their presence in less developed countries in terms of a commitment and a positive contribution to the progress of the new states. Eventually, British companies tried to "Africanize" their corporate image through these campaigns.
\end{abstract}

Tn n the 1930s and 1940s, British business in West Africa was faced with a rising tide of public discontent and criticism. Closely associated with the British Empire, imperial companies were attacked for monopolizing lucrative trades, discriminating against Africans, and colluding with colonial governments. After World War II, public disaffection focused on the close economic cooperation between governments and foreign business. African businessmen resented the preferential treatment that large merchant firms received in the import-and-export trade. But it was the continued high prices of imported goods like cloth, caused by a general supply shortage, coupled with relatively high incomes in West Africa, a result of the high demand for tropical

STEPHANIE DECKER is lecturer in International Business at the University of Liverpool Management School.

Acknowledgments: I am indebted to the Arts and Humanities Research Council and the University of Liverpool Research Development Fund for funding my doctoral research, out of which this paper developed, as well as the Economic and Social Science Research Council, which granted me a postdoctoral scholarship. I would also like to thank Stefanie van de Kerkhof, Dmitri van den Bersselaar, Stefan Schwarzkopf, and Gareth Austin for their help and comments on earlier drafts. Finally, the archivists of Barclays Bank DCO, Unilever, and Bank of West Africa (now Standard Chartered) have been unfailingly helpful during my research. I am especially grateful for their support in reproducing the images used in this article.

Business History Review 81 (Spring 2007): 59-86. (C) 2007 by The President and Fellows of Harvard College. 
commodities and raw materials, that prepared the ground for a boycott by African traders and consumers in the Gold Coast in 1947. In February 1948, events came to a head after the boycott ended: police opened fire on a demonstration in Accra, and widespread unrest ensued in the coastal and central areas of the Gold Coast. ${ }^{1}$ Rioters targeted the trading companies and looted their shops. British companies were not the only ones affected; Lebanese traders, among others, were attacked as well. Notably, the most prominent Lebanese, Anastasios G. Leventis, was spared, while the worst-hit company was the British United Africa Company (UAC), a subsidiary of the Anglo-Dutch multinational Unilever. Leventis escaped because he was a well-known and vocal supporter of the nationalist cause; he had sponsored articles in the nationalist newspapers extolling African advancement. ${ }^{2}$ Although the Lebanese traders were far from popular, the UAC was even more reviled. In 1948, the bell tolled for foreign companies, and their continued operation was threatened by the prospect of African nationalists taking over their governments in the near future. The year 1948 became a political watershed: the Colonial Office accepted the necessity of greater African participation and considered that self-government would be feasible within one generation. By the early 1950 s, the time frame for independence had become much shorter. While British officials continued to liaise with European companies in West Africa, they had also taken steps to distance themselves. Firms that had once been able to rely on official support were now too closely associated with the evils of colonialism.

In recent work on business and decolonization, Robert Tignor and Sarah Stockwell put forward the view that decolonization was characterized by a widening rift between colonial governments and British companies. ${ }^{3}$ Deteriorating relations with the colonial administration, however, pushed business to accept the changed political situation in the colonies. Despite areas of difference, colonial governments, African politicians, and British business could agree on a development framework, and this consensus aided companies in shifting their political

\footnotetext{
${ }^{1}$ Aiken Watson, Report of the Commission of Enquiry into the Disturbances in the Gold Coast (London, 1948); Dennis Austin, Politics in Ghana, 1946-1960 (London, 1964), 69-77; Florence Mabel Bourret, Ghana: The Road to Independence, 1919-1957 (London, 1960), 168-74; Richard Rathbone, "Introduction," in Ghana. Part I: 1941-1952, ed. Richard Rathbone (London, 1992), xliii-xlvii; Sarah Stockwell, The Business of Decolonization (Oxford, 2000), 70-90. Similar disillusion gripped Nigeria, but major riots did not occur. See Toyin Falola, Development Planning and Decolonization in Nigeria (Gainesville, 1996), 91.

2 E. W. Pearce to Mr. Rawlings, 31 Mar. 1947, papers of John Holt \& Co. (Liverpool) Ltd., mss Afr. s825, 421 A (iii), Rhodes House, Oxford.

${ }^{3}$ This argument has been made by Stockwell, The Business of Decolonization, and Robert Tignor, Capitalism and Nationalism at the End of Empire: State and Business in Decolonizing Egypt, Nigeria, and Kenya, 1945-1963 (Princeton, 1998).
} 
networks to the emerging elites in Ghana and Nigeria, a trend that became apparent in the post-independence period. ${ }^{4}$

Decolonization forced British companies to overhaul their entire operations, including their commercial and political strategies, their staffing policy, and their public-relations outreach. Improving their corporate images became essential, as they were determined to outstay the empire. One aspect of this new approach was increased advertising to African audiences. The corporate image created in these advertisements changed over time as the companies shifted from using imperial symbolism in the 1950 s to displaying images more representative of the new modernism in the 1960 s and 1970 . However, they were largely directing their efforts to the elites, whether in the United Kingdom or West Africa, underlining the defensive nature of their image overhaul.

Central to the companies' defense strategy were theories of economic development that became influential in the African political economy during decolonization. Frederick Cooper argues that the focus on development and modernization revived imperial aspirations in the British and French colonies, however unsuccessfully. ${ }^{5}$ Popularized ideas of economic development and modernization offered both former colonies and the imperial metropolis a place and a role in the international system. ${ }^{6}$ New states could make claims on their former rulers, while the imperial powers gained an image of benevolence in the twilight of colonialism. This was particularly important in the context of cold-war politics, a period when the United States was condemning imperialism and seeking to include the new states in the Western sphere of influence. ${ }^{7}$ The work of Walt Whitman Rostow, who based his forecast of the progress of new nations on the historical stages of developed nations' economic growth, provided such a general theory of development. ${ }^{8}$

Imperial businesses did not collapse alongside colonialism, but

\footnotetext{
${ }^{4}$ Toyin Falola argues that late colonial development planning profoundly shaped Nigerian conceptions up to 1980 . Falola, Development Planning, xi, 68-70, 91.

${ }^{5}$ Frederick Cooper, Decolonization and African Society: The Labor Question in French and British Africa (New York, 1996), 3-4, 451-72. The importance of development efforts has also been noted by imperial historians such as John Gallagher, The Decline, Revival and Fall of the British Empire (Cambridge, 1982); Peter Cain and Antony G. Hopkins, British Imperialism. II: Crisis and Deconstruction, 1914-1990 (London, 1993).

${ }^{6}$ Frederick Cooper and Randall Packard, "Introduction," in International Development and the Social Sciences: Essays on the History and Politics of Knowledge, eds. Frederick Cooper and Randall Packard (Berkeley, 1997), 12, 30.

${ }^{7}$ The demise of colonialism has been connected closely with the inability of the former Great Powers to maintain their empires in the face of two openly anti-imperialist superpowers. John Darwin, "Decolonization and the End of Empire," in The Oxford History of the British Empire. Vol. 5: Historiography, eds. R. W. Winks and Alaine Low (Oxford, 1999), 548-52.

${ }^{8}$ Walt Whitman Rostow, The Stages of Economic Growth: A Non-Communist Manifesto (Cambridge, 1960). The success of Rostow's work lay in its close fit with cold-war economic policies, and his challenging of the Marxist stage theory of development. See Goran Ohlin, "Reflections on the Rostow Doctrine," Economic Development and Cultural Change 9(1961): 654 .
} 
instead successfully adapted their operations by highlighting their role in the economic development of the continent. This provided a framework for them to cooperate, first with colonial governments and then with the new African elites, who were promising the electorate political independence and economic development. ${ }^{9}$ Economists like W. Arthur Lewis and Dudley Seers were appointed by the Colonial Office and then by successor governments to advise on economic policy. Many key ideas behind modernization and development theory made their way into the political discourse, albeit in simplified form. ${ }^{10}$

British businesspeople were aware of these trends, although they were not necessarily privy to the finer points of the debates occurring in political and academic circles. Reports by the British government sketched out a clear role for foreign business in its programs, as, for example, in its accounts of the disturbances in the Gold Coast in 1948." The clearest evidence of business initiating a role within the new economic regime comes from an internal memorandum that was circulated at Barclays in 1961, after six authorities on development economics had been consulted on the possible role of banking in Nigeria. ${ }^{12}$ Many companies adopted policies that governments perceived as beneficial, and in 1962 Unilever claimed that despite the government's defamation of business "the position of the [Nigerian] Government was basically the same as that of the Company."13

Why were companies so willing to engage with contemporary thinking about development and to accept political imperatives? Imperial businesses derived new legitimacy from the development efforts of the 1950 s and 1960s, since they could present themselves as one of the few sources of scarce capital, manpower, technology, and skills. This claim gave them access to elites in politics and business, a limited say in economic policies, and improved standing in African countries. Foreign companies inevitably justified their presence in poorer parts of the world based on the promise to deliver progress and modernization. ${ }^{14}$

\footnotetext{
${ }^{9}$ Stephanie Decker, "Building Up Goodwill? British Business, Development and Economic Nationalism in Ghana and Nigeria" (Ph.D. diss., University of Liverpool, 2006), 89-129.

${ }^{10}$ Tony Killick, Development Economics in Action: A Study of Economic Policies in Ghana (London, 1978), 11-32, 53-4.

"For example, see Watson, Report, para. 241.

12 "Developing a Middle Class in Nigeria," 20 and 30 Oct. 1961, Barclays Group Archive (hereafter BGA), 80/3468.

'3 Unilever Directors' Committee, 358. Nigeria, 11 May 1962, Unilever Historical Archives UNI/BD/DC.

${ }^{14}$ The idea that business has to justify its presence in society has been suggested in various different contexts. See Roland Marchand, Creating the Corporate Soul: The Rise of Public Relations and Corporate Imagery in American Business (Berkeley, 1998), 7-47; Stefan Schwarzkopf, "They Do It with Mirrors: Advertising and British Cold War Consumer Polities," Contemporary British History 19 (2005): 137-43; Timothy O'Brien, "The Revolutionary Mission: American Enterprise in Cuba," American Historical Review 98 (1993): 765-67, 781-84.
} 
However, by the mid to late 1960 s, belief in rapid progress was wearing thin. Ghana and Nigeria experienced coups in 1966, events that coincided with the radicalization of political and economic debates and increasing hostility to foreign business in many developing countries. ${ }^{15}$ As Western-advocated, noncommunist development failed in West Africa, its legitimacy eroded, and expropriations became a growing threat.

The argument that development themes entered advertising during decolonization has been made by Anandi Ramamurthy, who studies how Africans were represented to Europeans. ${ }^{16}$ However, as she does not analyze the shift in corporate representations to reflect the firms' position in African host countries, the extent to which the emphasis on progress and development was not just a European concern but also an African one is obscured. ${ }^{17}$

My focus in this article is on how advertisements reflected corporate intentions, not on consumer perceptions. Advertising was only one tool of a wider communication strategy. ${ }^{18}$ British companies used advertising to distance themselves from their old imperial identity. Hence, representations of Africans in corporate ads evolved in parallel with events, and they came to be shown not just as bystanders and consumers but increasingly as also occupying positions of responsibility. ${ }^{19}$

The following analysis of corporate-image ads begins with a discussion of a film that advocated the use of savings accounts in West Africa. Due to its success, however, the film became influential in shaping the sponsoring bank's future campaigns and in constructing its corporate image in Ghana and Nigeria. Print ads that were subsequently published during the 1950 and 1960 s illustrate the changes in the representation of Africans. One ad from the 1970s, discussed here, illustrates

\footnotetext{
${ }^{15}$ Kwame Nkrumah, Neo-colonialism: The Last Stage of Imperialism (London, 1968); Walter Bernecker and Thomas Fischer, "Rise and Decline of Latin American Dependency Theories," Itinerario 22 (1998): 25-45; Walter Rodney, How Europe Underdeveloped Africa (London, 1972); Samir Amin, Neo-colonialism in West Africa (Harmondsworth, 1973). Nevertheless, it is too simple to say that this trend ended with the 1970s, as many scholars continued to argue along those lines; see, for example, Toyin Falola, Britain and Nigeria: Exploitation or Development? (London, 1987).

${ }^{16}$ Anandi Ramamurthy, Imperial Persuaders: Images of Africa and Asia in British Advertising (Manchester, 2003).

${ }^{17}$ Cooper and Packard, "Introduction," 4, 12, 18, 30.

${ }^{18}$ The textual analysis of ads is based on an essay by Roland Barthes, "The Rhetoric of the Image," in Image, Music, Text (Glasgow, 1977), 33-47. Varda Langholz Leymore, in her book Hidden Myth: Structure and Symbolism in Advertising (London, 1975), viii, $x$, focuses on the interaction with value systems in society, while John Sinclair, Images Incorporated: Advertising as Industry and Ideology (London, 1987), 4-5, 29, emphasizes that ads are part of wider corporate strategies.

${ }^{19}$ This underscores that British companies in Africa increasingly Africanized their "shop front" and their management, and between the mid-1960s and the 1980 s most firms had almost fully Africanized their top management cadres.
} 


\section{Stephanie Decker / 64}

how business employed an Africanized corporate image to defend its presence on the continent. The final section argues that these ad campaigns addressed mainly elites, such as politicians, investors, and businessmen in Africa and Europe.

\section{Barclays' Put una money for there, 1956}

Branch banking was changed in the 1950 s by the Africanization of commodity marketing and trade. ${ }^{20}$ The foreign merchant companies followed a strategy of spatial centralization and product diversification after the war. This strategy came about as much for political as for commercial reasons, and it took colonial development plans into consideration. ${ }^{21}$ Industrialization and limited import substitution became important features of economic policy in the Gold Coast and in Nigeria. ${ }^{22}$ Hence, trading companies shifted their focus and began manufacturing some of the goods they once shipped. They withdrew from their widespread network of small trading stations, which they usually passed on to their African agents in a general move from small-scale retail to wholesale operations and department stores. In line with African demands and the wishes of the colonial government, they left "simple" economic activity to locals and pioneered more technology-intensive ventures. ${ }^{23}$

In contrast to the trading companies, the banks expanded. In British West Africa, two banks predominated: the Bank of British West Africa (BBWA), founded in 1894; and the Colonial Bank, founded in 1916, which amalgamated with other regional banks into Barclays Bank Dominion, Colonial \& Overseas (DCO), in 1925. ${ }^{24}$ After World War II, some foreign and indigenous banks opened. BBWA and Barclays, however, remained the largest branch bankers, and both expanded significantly in the 1950s. Initially, they conducted business largely with expatriate companies and had branches only in the largest cities. Nigeria

${ }^{20}$ Antony G. Hopkins, An Economic History of West Africa (Harlow, 1973), 273-80.

${ }^{21}$ Decker, "Building Up Goodwill?" 89-99, 109-16.

${ }^{22}$ For Ghana, see Miatta Fahnbulleh, "The Elusive Quest for Industrialisation in Africa: A Comparative Study of Ghana and Kenya, c.1950-2000" (Ph.D. diss., London School of Economics, 2005).

${ }^{23}$ This was referred to as redeployment, and was endorsed early on by colonial governments; see Watson, Report, para 241; United Africa Company, "Redeployment," Statistical and Economic Review 28 (London, 1963), 1-38; Peter Kilby, Industrialisation in an Open Economy: Nigeria, 1945-66 (Cambridge, 1969), 53-80; Hopkins, An Economic History, 276-79; Stockwell, The Business of Decolonization, 152-57; D. K. Fieldhouse, Merchant Capital and Economic Decolonization: The United Africa Company, 1929-1987 (Oxford, 1994), 679-715.

${ }^{24}$ For a short account of the foundation of the banks, see Richard Fry, Bankers in West Africa: The History of the British Bank of West Africa (London, 1976), 23-29, 91-93, 101-2. 
had the lowest bank-branch density of the entire British colonial empire; the Gold Coast, the sixth lowest. ${ }^{25}$ Hence, the two banks' services to companies like the UAC, which operated a network of hundreds of trading stations, was limited, because the company carried its own coin, organized transfers between its branches, and advanced credit to local traders and farmers. When the trading companies withdrew from the scene, they left vast tracts of territory with no external finance apart from indigenous credit institutions, which operated on a smaller scale. Neither the colonial government nor the emerging African nationalist elites wanted this situation to remain in place.

Nationalists criticized British banks for not giving credit to Africans and serving only foreign business. They claimed that this selectivity was due to racism, while the banks argued that many African customers lacked creditworthiness. ${ }^{26}$ Both colonial governments and their nationalist successors also wanted to increase the internal savings rate in order to finance further development projects, as it was widely understood in political and economic circles in Europe, North America, and Africa that this was how poor countries could be developed. ${ }^{27}$ Both BBWA and Barclays began to expand their branch networks, particularly in the early 1950s, and started to compete, initially for local savings and later also for overdrafts and credits.

This was the background that led Barclays to order a cinema spot from the English Larkin Studios, a state-of-the-art British animation studio. ${ }^{28}$ This film presented a fairly traditional, colonial view of Africa,

\footnotetext{
${ }^{25}$ Measured by the total number of branches in relation to population figures. See Walter Newlyn, "The Colonial Empire," in Banking in the Commonwealth, ed. Richard Sayers (Oxford, 1952), 450.

${ }^{26}$ The bankers' notion of creditworthiness nevertheless had racist undertones, as bankers assumed that Africans were stealing and lying (especially from Europeans) whenever possible. Whether this (mutual) distrust between Africans and Europeans really resulted in higher levels of fraud is unclear. Moreover, property rights in Africa could not always be passed on to Europeans. Especially with regard to land rights, the situation was complicated. Colonial governments made African-owned land in many parts of the colonies inalienable to foreigners, in order to prevent settlements and plantations. While this policy benefited independent African farmers, it made it difficult for local owners to mortgage their land or property to a foreign bank, since the bank could not take up the title. Hence, Africans had difficulty providing security for loans. On the nature of property rights, see Gareth Austin, Land, Labour and Capital in Ghana: From Slavery to Free Labour in Asante, 1807-1956 (Rochester, N.Y., 2005), 443-45, 453-54.

${ }^{27}$ Mobilizing savings and expanding financial institutions were presented as key features for take-off in W. W. Rostow, "The Take-off into Self-sustained Growth," Economic Journal 66 (1956): 29-30, 38-40, 46-47. See also W. Arthur Lewis, "Economic Development with Unlimited Supplies of Labour," Manchester School (May 1954): 416. "Big-push" development economics were embraced by Nkrumah's government; and acceptance of these ideas was widespread. See Killick, Development Economics in Action, 17-20.

${ }^{28}$ Larkin Studios featured heavily in a recent three-part documentary on the history of British animation shown on $\mathrm{BBC}_{3}$, Animation Nation, especially in the first part on advertising, "The Art of Persuasion."
} 


\section{Removed for copyright reasons}

Pictures from the booklet that accompanied the film Put una money for there produced by Barclays Bank DCO. (Source: videotape, BGA 1114/1; concertina leaflet, BGA 1174/36. Courtesy of Barclays Group Archives, Barclays Bank, U.K.)

as the depiction of the village and the simple clothing worn by the participants indicates. However, there were some hints of the modernization that was beginning to take place in the African countryside: the inside of a hut has electric light, and a farmer travels to the Barclays branch on a unicycle. The branch building itself is depicted as having colonial-style architecture.

The savings film was a great success, winning the Grand Prix du Festival at the International Festival of Advertising Film-Makers at Cannes in 1956. Even more important, it was hugely popular with West African audiences. ${ }^{29}$ This reception had not been foreseen. Indeed the local director, Leonard Daldry, had tried to stop the release of the film, as he was concerned that the opening scene showing three African farmers sliding down palm trees made them look like monkeys and would be considered offensive by local audiences. ${ }^{30} \mathrm{He}$ was eventually overruled.

Once the film was finally released, much of its success was attributed to the soundtrack: highlife music composed and performed by the Ghanaian Sam Akpabot in West African Pidgin. The film addressed some West African sensibilities more successfully than its creators had anticipated. In his memoirs, the British expatriate banker Hugh Norris recalled:

The cartoon proved to be an instant sensation of the very best kind: audiences roared with laughter, particularly at the second farmer

${ }^{29}$ Barclays Bank DCO, Board Minutes, ledger vol. 9, 22 Mar. 1956, 38; 27 Sept. 1956, 129; BGA $38 / 511$.

${ }^{30}$ Hugh Norris, "A Little Family History, Part Three-My Own Story, Book Four: 19491984, "Overseas Banking," 70, BGA 1083/1. 
being robbed by his wife. The film had originally been assigned a useful life of no more than one year, and was succeeded by others; but its successors were pale shadows by comparison, and the original cartoon continued to play a part in our publicity right up until the time I left Nigeria in $1968 .^{31}$

It is revealing that the audience reacted to the scene between the husband and wife. Conflicting demands on people's incomes are still perceived as difficult by many Ghanaians and Nigerians. Family members and the wider community expect generosity from successful individuals as a marker of achievement. These demands can quickly outstrip the donor's funds. While flaunting one's wealth is acceptable, many are keen to keep the true extent of their financial position hidden in order to discourage people from seeking their support..$^{32}$ Fear of borrowers could be as pressing a concern to African audiences as fear of robbery. Hence the ad, despite its naïve setting and simple structure, offered a symbolic solution to the problem of how to deal with wealth and the social obligations that come with it. Douglas Holt has pointed out that ads which refer to pressing contemporary issues in a society have often been immensely successful, and he refers to them as a form of "iconic branding." 33

A more far-reaching explanation relates to what Holt describes as the social and historical backdrop that makes an iconic ad so relevant. While the film's animation was slick by the standards of the 1950s, and the story featured dilemmas with which audiences could identify, the success of Put una money hinged on the music. Ghana in the 1950s was a musical trendsetter through its creation of the "highlife" style, which dated from the 1930 s but became hugely successful and influential in the 1950s, fueled by the contribution of musicians like E. T. Mensah. Highlife was not just popular entertainment: musicians openly supported the nationalist politician Kwame Nkrumah in their lyrics and with their performances. ${ }^{34}$ Barclays' Put una money tapped a rich cultural chord through its choice of music. "The sound track of the film was frequently played," noted Brian Macdona, a manager visiting from the London head office in 1958. "The reaction of the public to the 'HighLife' tune was, I gather, vociferous. The crowd sang and stamped their

\footnotetext{
${ }^{31}$ Norris, "Overseas Banking," 70.

${ }^{32}$ W. W. Milne, "General Report on Visit to West Africa," 9 June 1946, 6, BGA 38/906; Jean-François Bayart, The State in Africa: The Politics of the Belly (London, 1993), 242-43.

${ }^{33}$ Douglas Holt, How Brands Become Icons: The Principles of Cultural Branding (Boston, 2004), 6-10.

${ }^{34}$ The particular importance of highlife music for anticolonial nationalism and postindependence nation building lay in the nontribal, yet specifically African, even pan-African, credentials of its heritage. See John Collins, "A Social History of Ghanaian Popular Entertainment since Independence," Transactions of the Historical Society of Ghana, n.s. 9 (2005): 19-24.
} 
feet to the rhythm of the music and there was a very great demand for the concertina leaflets." 35

Another incident described by Macdona took place at a funeral procession of about one thousand people in Cape Coast that reveals how closely the bank had become associated with the ad.

The solemnity of the occasion was slightly impaired when one very grave and important looking gentleman who was reaching-in full voice-for the "Rock of Ages"-caught sight of [the new manager in Cape Coast], popped his head in the car, said "Ah, Barclays Bank, Put Una Money for There," winked violently, beamed, resumed his place in the procession and took up the hymn, again in fine voice. ${ }^{36}$

While none of these incidents indicate any political connection, it seems that Barclays, through its choice of music and to some extent its selection of subject matter, was, in the words of Macdona, more "on the ball" than its competitor, the BWA. ${ }^{37}$ Highlife music was not entirely political, but it was nevertheless closely associated with ideas of an "African renaissance," as it captured the optimistic spirit of a time when more Ghanaians and Nigerians actually had disposable incomes for which they required bank accounts.

Not only had the public reaction been a success, but the bank's savings and deposits increased to a greater degree than its directors had anticipated. ${ }^{38}$ Whether this was entirely due to advertising, or to one film in particular, is doubtful. Nevertheless, it does indicate that the bank's promotional activities met with some success. A second savings film, Wahala Kamot (by the British animator Dick Taylor), followed in the 1960 s that worked the winning elements of its predecessor in a similar manner. The film's protagonist, a successful African Barclays customer, was featured dispensing advice, thus Africanizing the bank's image.

In the 1960s, however, the paternalism that was evident in Barclays' films became less tenable.

\section{"Progress and a Bright Future" in the 1960s}

Ghana became independent in 1957, and Nigeria threw off its colonial status in 1960. Africans were now in charge of both government and administration, and they increasingly took up important posts in

\footnotetext{
${ }^{35}$ Brian Macdona, "Visit to Sierra Leone and Ghana, February-April 1958," verbatim notes from dictaphone, 27, BGA 38/382 (4) (hereafter Macdona, "Visit to Sierra Leone and Ghana").

${ }^{36}$ Macdona, "Visit to Sierra Leone and Ghana," 72.

${ }^{37}$ Ibid., 27.

${ }^{38}$ Richard Fleming and E. V. Whitcombe, "Nigeria and the Cameroons," 23 July 1960, 19, BGA 80/3466.
} 
the economy as well. The popular belief of the 1950 s that prosperity and economic growth were the natural companion of African selfdetermination made it easier to expect that the 1960 s would be a "decade of development." When prices for tropical commodities stagnated, and then declined, after 1955, countries drew on their sizable sterling balances, and marketing boards' profits were skimmed off for development projects and conspicuous consumption. Failing development policies and economic mismanagement were factors that contributed to the military coups that toppled both Ghana's and Nigeria's governments early in 1966, but they did not entirely destroy the belief of Africans and foreigners alike in the countries' potential for development.

The ads discussed in this section were published in West Africa magazine, one of the highest-quality publications of its time. ${ }^{39}$ In 1987 , the magazine had a weekly circulation of 22,000, half in Africa, half in Europe and North America, reflecting the change in readership, which had once been limited to European expatriates in the 1930 s and 1940 s but had come to include African politicians, intellectuals, and businessmen, both in Africa and abroad. At its most successful, its publisher distributed 14,000 copies a week in Nigeria alone. ${ }^{4^{\circ}}$ Most companies operating in West Africa advertised in the magazine, and they normally ran the same campaigns in West Africa and in the local press. The magazine was a crucial advertising tool, as it reached the elites and decisionmakers in Africa, Europe, and North America.

The portrayal of Africans in British company advertising changed drastically, beginning in the late 1950 s and continuing through the 1960s. Representations of a traditional people made way for depictions of a new type of African: the upwardly mobile urban progressive. This transformation is best illustrated by UAC's ad "Men of Tomorrow," which emphasizes progress, training, and manufacturing.

In this ad, the UAC underlines its role in developing local skills through training, but the company also displays its industrial credentials in the bottom half of the picture, where the text is framed by cranes, ships, lorries, towers, planes (the symbols of modernity, progress, and development), and the occasional palm tree (to remind consumers that the ad is a depiction of West Africa). The slogans embody the spirit of the "decade of development": the concepts of skill and technology are conveyed hand in hand with the idea of industrial investment. The Africans pictured in the ad epitomize the 1950s businessman, and the

\footnotetext{
${ }^{39}$ Kaye Whiteman, “Obituary: David Williams," Independent, 23 Sept. 1993; "David Williams," Times, 17 Sept. 1993.

$4^{\circ 0}$ This is presumably in the late 1970 s and early 1980s. See David Pallister, "Media: A Rift between Continents-David Pallister on a Power Struggle between London Editor and Lagos Bosses," Guardian, 3 Sept. 1990.
} 
Stephanie Decker / 70

Removed for copyright restrictions

UAC ad, “Men of Tomorrow: The Sales Manager," 1959. (Source: West Africa magazine, Jan. 16, 1960, p. 64. Reproduced with kind permission of Unilever.) 


\section{Corporate Legitimacy and Advertising / 71}

setting could have equally been in North America or Europe. Again, examples of modern equipment, such as a typewriter and a telephone, accompany the main image. The visual framework, featuring an energetic young African salesman in the center, is that of a pyramid, and the chart behind the desk in the office shows rising sales figures, all visual clues that suggest movement and upward advancement. As the universal values of the development discourse became dominant, smiling farmers in need of guidance were banished from ads and young professionals were brought in.

The components of "Men of Tomorrow" are in stark contrast to the features of an earlier UAC campaign featuring colonial people that ran in 1955. "Colonial Customers" describes Africans in terms recognizable to Europeans. The UAC ad displays an inventory of traded commodities in a panel next to a market scene containing African women clothed in traditional attire, selling items to a man in a Western shirt and hat. Female economic activity is described as circumscribed by tradition, a point that is underlined by the downcast gaze and passive pose of a woman in the photograph adjacent to the text.

Both Barclays and BWA still used print ads in 1960 that were not very different from the ones they had published in 1945. BWA continued to advertise its services to investors in West Africa in terms of "specialist knowledge solidly acquired through long experience." At the same time, Barclays showed off its local knowledge, as demonstrated in its ad paying tribute to Accra's surfboat crews, ending with the statement that Ghana was a "steadily progressive country." ${ }^{41}$

By the 1960s, advertising campaigns had changed. They reflected an increased African readership as well as an audience made up of European investors. Barclays' campaign, however, remained oddly paternalistic, relying on humorous depictions of black children, representing their home countries' bright futures. In this campaign, children emulated professional adults. One of the ads (not shown here) depicts a young girl posing as a teacher. She stands at a blackboard looking boldly at her "class" of dolls over a turned shoulder. However, her assertive stance is undermined by the fact that she is dressed only in underpants and shoes and socks. The texts of the ads explicitly connect the children's growth to the maturing of their countries, emphasizing the opportunities that were opening up for them.

The bank managed not only to point out its own contribution to this bright future but also continued to represent itself to European readers as an expert with "unrivalled knowledge of local conditions and market trends." The layering process remained in other print ads of the

${ }^{41}$ Barclays, “Accra," West Africa, 9 Jan. 1960. 
Stephanie Decker / 72

Removed for copyright restrictions

UAC ad, “Colonial Customer," 1955. (Source: West Africa magazine, July 23, 1955, p. 686. Reproduced with kind permission of Unilever.) 
Corporate Legitimacy and Advertising / 73

Removed for copyright restrictions

Barclays Bank DCO ad. (Source: West Africa magazine, Jan. 9, 1960. Courtesy of Barclays Group Archives, Barclays Bank, U.K.) 
time, as the new theme of development only partially superseded the old claims of regional expertise, reflecting an attempt to cover all bases and to address the widest possible audience. Such a strategy was rational at a time when experts believed that African societies were "in transition" (from traditional to modern), and magazines like West Africa were read by expatriate administrators and businessmen, as well by as their emerging African successors.

The Bank of West Africa countered Barclays' campaign in the same year with its "Progress" series, which has a more industrial feeling, showing a refinery, a factory, and a ship at a loading dock. Despite the series' documentary appearance, the images are drawings, not photographs, rendered in a clear, solid style, and the ad is almost devoid of human beings. Drawings might have been used either to avoid reproduction costs or to offset the lack of detail in photographs. The ad's "modern" images contrast with the colonial-style logo of the bank, an oval containing a palm and an elephant, a commonly used combination in West Africa. While the bank had deferred to local sensibilities by dropping the word "British" from its name in the 1950s, surprisingly it did not alter its imperial-style logo, suggesting that it remained somewhat ambivalent about ceding this aspect of its identity.

In the text, the bank points out its willingness and ability to serve as an economic development resource. Like Barclays, this new service was added to its old function of supplying regional expertise, highlighting the fact that many of the banks' large customers were still foreign investors. Claims of local expertise remained part of banks' advertising even in the 1970s, when Barclays launched a campaign in which-in a reversal of financial flows-it presented itself as an experienced advisor to Nigerian investors abroad. ${ }^{42}$

The ads described show the type of campaign that ran in the $1960 \mathrm{~s}$. All of them, however, began to incorporate the subject of development, whether in their texts or in their images, or in both. None was quicker to do this than the UAC. The final ad discussed in this section, which was published in 1960 under the title "Change in West Africa," is a good point of comparison for a UAC ad that appeared ten years later and dealt ostensibly with the same subject but applied a different treatment in response to contemporary economic and political crises. In the earlier ad, shown here, a closed hall replaces the traditional open market, representing the arrival of progressive economic relations. The new building, epitomizing "change," is modern, but its location in the middle of a traditional market scene suggests that it was designed to fit neatly

\footnotetext{
${ }^{42}$ Barclays Bank Nigeria, "How Barclays Can Help to Protect Your Business Interest in Other Countries," Management in Nigeria (Nov. 1976): 33.
} 
Corporate Legitimacy and Advertising / 75

Removed for copyright restrictions

UAC ad, "Change in West Africa," 1960. (Source: West Africa magazine, Apr. 23, 1960, p. 475. Reproduced with kind permission of Unilever.) 
with existing institutions. Hence, the "change" referred to in the title implies that ongoing traditions are being upgraded, or improved.

In the text, UAC connects its own and West Africa's past and current history, maintaining that the company had, since its inception, worked for the area's economic development. The UAC listed all the benefits it offered to Ghana and Nigeria, mainly in the categories of investment and know-how. West Africa's needs, however, were seen purely in economic terms. Indeed, as one of its past achievements, the company, remarkably, listed "stimulating the desires that make progress possible," a goal that radical authors like Walter Rodney would later identify as a cause of the region's underdevelopment and continued dependence. Already, in the 1950s, the advertising industry faced criticism in the United Kingdom for stimulating "unnecessary" desires and needs. ${ }^{43}$

Multinationals were still tolerated in African societies, but in the late 1960 s, they began to encounter more hostility in the international environment.

\section{A Crisis of Corporate Legitimacy}

A final ad reflects the crisis of West African states and the rise of radicalism in the 1970s. While that decade is usually associated with the increased power of third-world countries, especially those possessing oil deposits, it also represented a phase of worldwide economic slowdown and import-substitution policies in the developing countries (with the exception of South Korea and Taiwan). Political volatility and military dictatorships became commonplace in Africa. Ghana returned to democracy in 1969 for three years, only to witness another military coup in 1972. Nigeria continued to be ruled by the military from 1966 until the late 1970s, although the regime changed in 1975. The discovery of oil fueled regional, ethnic, and religious tensions over the distribution of public funds. The secession of the eastern region in 1967 led to the Nigerian civil war, which lasted until 1970.

By 1970, the Nigerian federation had prevailed, and the attention of the military government shifted to the economy. In 1968 and 1969, company legislation was updated, forcing foreign businesses to incorporate locally and to fulfill local content requirements. In 1972, the first Nigerian enterprise promotion decree was promulgated, ensuring Nigerian participation in business by forcing existing foreign owners to sell to Nigerians. The categories requiring Nigerian ownership were roughly

\footnotetext{
${ }^{43}$ For an influential criticism of advertising, see John Kenneth Galbraith, The Affluent Society (London, 1974, 1st ed., 1958), 150-51; and Schwarzkopf, "They Do It with Mirrors," 135-7. See also Frank Trentmann, "Beyond Consumerism: New Historical Perspectives on Consumption," Journal of Contemporary History 39 (2004): 376-81.
} 
determined by levels of capital, technological sophistication, and degree of expertise necessary to maintain operations. Foreign businesses were forced to sell equity or assets of either 100 percent or 40 percent. Normally, small enterprises involved in comparatively "simple" economic activities, such as retail trade, passed into Nigerian hands. The decree applied mainly to resident Lebanese and other African nationals. The oil and petroleum sector was covered by separate legislation. ${ }^{44}$

In Ghana, such business-participation programs had come into force in 1968 and 1969, and they mainly targeted smaller foreign companies, especially those owned by Lebanese businesspeople. Balanceof-payments problems had limited the free convertibility of money, and companies' leeway to repatriate profits had been curtailed. Ghana was in the throes of a major economic crisis that continued through the 1970 and 1980s; it followed Nigeria's example by promulgating a decree in 1975 that forced foreign businesses to sell to indigenous owners.

As African politicians in less developed countries became aware of global developments in the 1960 s and 1970s, they resorted more often to expropriations of corporate property. ${ }^{45}$ The graph shown in Figure 1 does not demonstrate a widespread takeover of control by less developed countries. Cases involving the transfer of most of a company's shares did not necessarily result in local control, as management and technical contracts were common, in effect leaving operational, and often strategic, control in the hands of the former owners. The graph does show, however, that around 1970 companies encountered their first expropriations. Thus, the managers had to be aware of the rising tide of global economic nationalism that potentially endangered their investments abroad. Business leaders had no way of knowing in advance

\footnotetext{
${ }^{44}$ Thomas Biersteker, Multinationals, the State, and the Control of the Nigerian Economy (Princeton, 1987). See also Adeoye Akinsanya, Economic Independence and Indigenisation of Private Foreign Investments: The Experiences of Nigeria and Ghana (Columbia, S.C., 1982).

${ }^{45}$ Geoffrey Jones, The Evolution of International Business: An Introduction (London, 1996), 293. Most expropriations occurred in Africa ( 52.1 percent), followed by Latin America (28.7 percent) and North Africa and the Middle East (25.9 percent) according to Kobrin for the time period 1960-79. British firms were also most likely to be expropriated in Africa (49 percent), but less likely than their peers to lose their investment in the Middle East (19 percent) or Latin America (8 percent). This might reflect different regional distribution. Internationally, the manufacturing sector was worst affected ( 26 percent), followed by petroleum (17.7 percent), mining and finance (12.1 percent), and agriculture ( 8.8 percent). Here, British experience diverged distinctly: extractive companies were most affected ( 30 percent), then $\mathrm{fi}$ nance (20 percent), followed by manufacturing ( 15 percent) and agriculture (13 percent). The United States' investment in Latin America probably explains why British companies were affected differently than the overall pattern suggests. For the international figures, see Stephen J. Kobrin, "Expropriation as an Attempt to Control Foreign Firms in LDCs," International Studies Quarterly 28 (1984): 336; for British companies, see Fiona Boyd, "Expropriation of Alien Property in International Law: A Study of Recent State Practice Concerning British Nationals" (M. Phil. diss., University of Nottingham, 1988), 37, 43.
} 


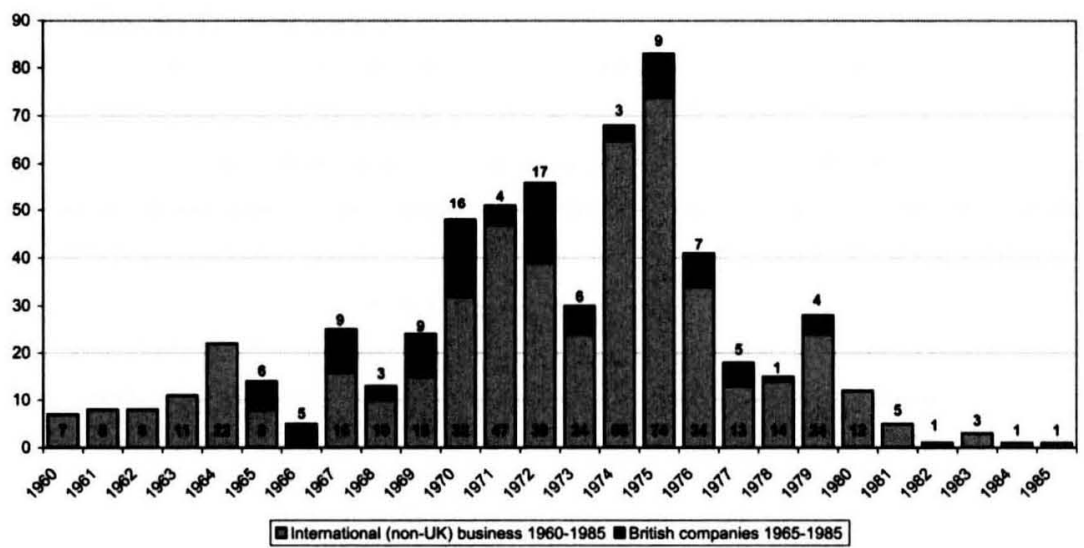

Figure 1. Incidents of expropriation acts against multinational companies worldwide, 196085; and against British companies, 1965-85. (Source: Charles R. Kennedy, "Relations between Transnational Corporations and Governments in Host Countries: A Look into the Future," Transnational Corporations 1 (1992): 69; Fiona Boyd, "Expropriation of Alien Property in International Law: A Study of Recent State Practice Concerning British Nationals" [Master's thesis, University of Nottingham, 1988], 29.)

that many transfers of ownership would not always entail a loss of control, but, no matter what the circumstance, they still would have sought ways to protect their investments.

The final ad embodies, as few others do, the crisis of neoclassical development theories and the response by business. It appeared shortly after the end of the Nigerian civil war in 1970. The timing and location of its publication are interesting: the ad was carried in Nigeria, a magazine directed to a culturally conscious black audience. ${ }^{46}$ The $1970-71$ edition in which the ad was published featured readers' poems criticizing African women for using skin-lightening creams and lamenting the cultural dominance of white beauty ideals.

The title chosen by UAC, "the LAND, the GROUP and the ROLE," was a response to this changing climate, and the images reflect each part: The land is evoked by a sketch of skyscrapers, suggesting progress and development. Interestingly, it is the only image that is not a photograph, and the insubstantial style in which the skyline is rendered seems to suggest either receding hopes or a distant future. The ad's

${ }^{46}$ Nigeria had been founded in the late 1940 s by a colonial education officer, originally as a private initiative. Its success prompted the Nigerian colonial government to take over the magazine as a quarterly publication on the arts and culture in Nigeria. As a state-owned venture, it was presumably taken over by the independent Nigerian state, but information on the subsequent fate of the magazine is patchy. Colonial Office, Colonial Annual Reports: Nigeria, 1947 (London, 1949), 79-80. 
Corporate Legitimacy and Advertising / 79

Removed for copyright restrictions

UAC ad, "the LAND, the GROUP and the ROLE," 1970-71. (Source: Nigeria magazine, no. 1079, Dec.-Aug. 1971, p. i. Reproduced with kind permission of Unilever.)

Reproduced with permission of the copyright owner. Further reproduction prohibited without permission. 
theme is similar to that of "Men of Tomorrow," in that the group is represented by a smiling young African executive, in this case pointing toward the UAC logo. A photo insert of what is possibly a textile factory shows an African supervisor instructing a worker, thereby passing on his knowledge and ensuring productivity. By pointing to the machine, he mirrors the gesture of the young executive. These images recall the visual language used in the "Men of Tomorrow" campaign, and they propagate the same values. Most critically, the text gives a good idea of the changed environment the company was facing by the 1970s.

By 1970, most of UAC's profits came from Nigeria, and the majority of Unilever's revenue came, in turn, from UAC. Hence, both subsidiary and parent had become dependent on the West African country. ${ }^{47} \mathrm{UAC}$ began to emphasize its contributions to the country's development in order to protect its valuable assets and profits from expropriation. The UAC claimed, in "the LAND, the GROUP and the ROLE," that it was extending itself wherever need arose, that it was helping to support education, and that it was sharing the life of the community. Its concerns were "social welfare ... youth, ... and the affairs of the needy." The first section of the text stresses the company's social role, a contrast to its earlier orientation toward training and supporting the country by creating growth. With this shift in emphasis, the company appeared to address concerns about the social costs of development.

The second section of the ad, however, covers more familiar territory. UAC's managers serve to "further the progress ... of the people of the Land" and to improve efficiency and standards; the resulting "benefits ... are shared with the Land." In this long text, the company supplies a new interpretation of development, one that is less technocratic, less focused on large-scale industrial projects, and more concerned with the welfare of people, inspiring its determination to create jobs, provide social support, and ensure a wider, more equitable spread of economic gains. Essentially, the initial idea of development as growth has been superseded by the notion of development as a path leading to greater welfare and equality in society.

However, the UAC tried to connect the idea of growth as a basic necessity with the notion of equality. Clearly, a company could not subscribe to a radical notion of redistribution, but it could easily accommodate different ideas about growth. Theories of underdevelopment no longer cast multinationals as engines of growth but referred to them as agents of exploitation, a designation that stripped foreign business of its legitimacy. While "the LAND, the GROUP and the ROLE" illustrates

\footnotetext{
${ }^{47}$ Fieldhouse, Merchant Capital, 620, 718, 721, 762, 774; Geoffrey Jones, Renewing Unilever (Oxford, 2005), 57, 79, 197.
} 
a firm's attempt to counter this perception, eventually, in the discourse of the 1970s, firms were unable to come up with new sources of legitimacy for their activities. British companies defended themselves with worn-out arguments and resorted to their old strategy of seeking connections to administrators and politicians in order to influence policies. These connections were considerably harder, though not impossible, to achieve in Nigeria and Ghana when military rulers were in place, as they were for most of the period from 1966 to 1979.

In the 1970s, all large foreign companies were eventually forced to sell parts of their equity locally; however, only a few lost control of their investments. Among the latter were the British banks in Nigeria and the timber operations run by the UAC in Ghana. The legislation's impact was relatively limited because the Nigerian government did not seek to break all ties with multinationals but continued to subscribe to a capitalist, relatively open economic system. Although the Ghanaian government took a more radical approach, it nevertheless allowed foreign companies to continue their operations. The country also showed that it respected international property rights by paying compensation. Impoverished Ghana was hardly able to nationalize all foreign businesses, whereas Nigeria, flush with petrodollars, would have been able to nationalize many more. Hence the threat of nationalization was less intense in West Africa than it was, for example, in Tanzania, Egypt, Iran, Uganda, or some Latin American countries. ${ }^{48}$

While the rise in expropriations seems impressive, it did not result in a global transfer of corporate power, and, by the late 1970s, the challenge to corporate legitimacy in the developing world seemed to abate. Even in cases where majority ownership became local, the relevant technology was sometimes patented; management and service contracts had often been agreed to earlier; or qualified staff were simply not available and had to be hired back from the previous owners.

\section{Elite Discourse and Corporate Legitimacy}

The ads I have analyzed in this article often served more than one purpose and were directed to more than one type of audience. However, the ongoing discourse between elites in politics and business was crucial.

\footnotetext{
${ }^{8}$ Robert Tignor, "Decolonization and Business: The Case of Egypt," Journal of Modern History 59 (1987): 479-505; Robert Tignor, "The Suez Crisis of 1956 and Egypt's Foreign Private-Sector," Journal of Imperial and Commonwealth History 20 (1992): 274-97; Caroline Piquet, "The Suez Company's Concession in Egypt, 1854-1956: Modern Infrastructure and Local Economic Development, "Enterprise \& Society 5 (2004): 107-27. For Iran in the 1950s, see Geoffrey Jones, Banking and Oil: The History of the British Bank of the Middle East, vol. 2 (Cambridge, 1987). For Latin America, see Paul Sigmund, Multinationals in Latin America: The Politics of Nationalization (Madison, Wisc., 1980).
} 
The print ads were placed in prominent magazines and newspapers, which were read by the proportion of the population in West Africa that was literate (in the 1950s and 1960s, this segment rarely equaled more than one-third of the whole) and reasonably well educated. ${ }^{49}$

The Barclays' savings film, Put una money for there, however, with its stated intention of imbuing the (often illiterate) African farmer with the idea of thrift and with a savings account, seemed to address a different audience altogether. The strong attraction of its highlife music, sung in Pidgin English, suggests that the semiliterate, semiskilled, newly urbanized "intermediate" groups of West African society were most effectively targeted. This class, sandwiched between the national elites and the poor subsistence farmers, was politically most powerful during decolonization. Politicians like Kwame Nkrumah drew their support from its members, who had precisely the most to gain from independence and economic development and whose votes were important to nationalist politicians.

Despite the efforts of the bank to present the film at agricultural shows, it is doubtful that the rural population comprised its main viewers. The film reached a wider audience in urban areas, where it was shown in cinemas. In 1954, Nigeria had forty commercial cinemas; the Gold Coast, twenty-eight. In the Gold Coast, seventeen of these movie houses were in major urban centers like Accra, Kumasi, and SekonkiTakoradi; the rest were in smaller provincial hubs. In Nigeria, thirty of forty cinemas were in the western region and in Lagos. ${ }^{50}$ Thus it was unlikely that a large proportion of the rural population had a chance to see it. Nevertheless, the presence of movie houses was not the whole story. Colonial governments all across the continent experimented with mobile film units. In the Gold Coast, so-called Aban cinemas, or government mobile film units, were established in $1940 .{ }^{51}$ Thus, while audiences must have been predominantly urban, the film probably reached rural audiences to some extent.

\footnotetext{
49 In Ghana literacy rose from between 19 percent to 23 percent for males around 1950 to 43 percent for males and reached 17 percent for females in 1970. In Nigeria, English literacy was lower c.1950, between 10 and 15 percent, but it also rose to 31 percent for men and came to 10 percent for women in 1970 . (The percentages refer to people age fifteen and over.) Richard Jolly, Planning Education for African Development: Economic and Manpower Perspectives (Nairobi, 1969), 104, table IV-1; Frederick Cooper, Africa since 1940: The Past of the Present (Cambridge, 2002), 114, table 2.

${ }^{50}$ Colonial Office, Report on the Gold Coast for the year 1954 (London, 1956), 104; and Report on Nigeria for the year 1954 (London, 1958), 188. Although Nigeria's western region was rural, it was also affluent and densely inhabited due to cocoa farming.

${ }^{52}$ Collins, "A Social History," 19. For an image from 1950, see Colonial Office, Colonial Reports: Gold Coast, 1950 (London, 1952), between pp. 54 and 55. While there is no information on West Africa, in Zimbabwe these units showed ads before and after films. Timothy Burke, Lifebuoy Men, Lux Women: Commodification, Consumption, and Cleanliness in Modern Zimbabwe (Durham, N.C., 1996), 141.
} 
However, when it was first presented in West Africa, local managers questioned the representation of Africans in the film, underlining how important the opinions of African elites were to the bank. Brian Macdona pointedly remarked at an agricultural show in 1958 that the governor-general had approved of Barclays' advertising. ${ }^{52}$ That Put una money for there was mentioned prominently by Julian Crossley, the bank's chairman, at the annual general meeting suggests a political subtext of the savings campaign: it was an exercise designed to gain the approval of African and British colonial elites for the project.

The representation of Africans in corporate advertising changed from bystanders (in BBWA's early print ads) or types (in UAC's campaign around 1950) to customers and employees (in Barclays' film and UAC's "Men of Tomorrow" ad). This marked an important shift in perception as Africans came to be portrayed in more active and assertive roles. By 1970 , UAC was using the image of an African manager. It is not clear to what degree these ads were negotiated by creative agencies and firms or whether African imagery mattered in this process at all. ${ }^{53}$ The transposition of corporate intentions into the visual and textual shorthand of advertising, and its reception in Africa, Europe and North America, still requires further research.

\section{Conclusion}

The plan to develop its tropical colonies offered a new source of legitimacy, not only to British imperialism but also to British business. While this new justification of imperial rule remained short-lived and could not prevent the arrival of independence of Ghana in 1957 and of Nigeria in 1960, it remained relatively uncontested in the business world until the late 1960 s and $1970 s .{ }^{54}$ By the 1960 s, companies were reconstructing their corporate images, stressing their willingness to cooperate in the progress of West Africa and their ability to deliver capital and know-how to aid the region's development. Firms began to portray their

\footnotetext{
52 Macdona, "Visit to Sierra Leone and Ghana," 27.

${ }^{53}$ Assertive poses cannot be equated with a "decolonized" representation of Africans. Indigenous photography shows different poses from colonial imagery and corporate advertising. For an introduction to the debate, see Anne Maxwell, Colonial Photography and Exhibitions: Representations of the "Native" People and the Makings of European Identities (London, 1999), 13-14; and the criticism by Erin Leigh Haney, "If These Walls Could Talk! Photographs, Photographers and Their Patrons in Accra and Cape Coast, Ghana, 18401940" (Ph.D. diss., School of Oriental and African Studies, University of London, 2004), 182-213.

54 of course there had been criticism of foreign multinationals before the 1970s, most notably Chief Awolowo's motion for nationalization in the Nigeria parliament in 1961. His party had already become the focus of foreign business criticism during decolonization. See Tignor, Capitalism and Nationalism at the End of Empire, 239-41.
} 
own function as serving the needs of developing economies, and thus they justified their presence as first-world businesses in third-world countries.

After 1948, when local political reforms and decolonization began to dominate life in the colonies, firms slowly realized the need for an active public-relations strategy, and this awareness had an impact on advertising. In the 1950s, companies began to refer to "development" in their campaigns. By the mid-1960s, advertising was taking up the themes of progress and industrial development.

As advertising began to reflect development concerns, the representation of Africans changed. In the savings film Put una money for there, Africans were still pictured as childlike, trapped in a traditional world containing few objects that pointed to the possibility of a brighter future. Print advertising similarly showed Africans in "typical" situations, often framed by explanatory text for European audiences. This perspective changed, but only slowly, during the late 1950 s and 1960 s. The UAC's "Men of Tomorrow" was the clearest break with the earlier tradition of advertising. Images reflected Africans' aspirations, and they were pictured as "young executives" in modern settings. Africa was no longer depicted as a "timeless" or "traditional" place, but rather as a site of activity, growth, impatience, and learning. However, the transition was not smooth, and colonial tropes continued to appear. Some new ads were either deeply paternalistic or dully technocratic. BBWA's campaign showed drawings of industrial installations in West Africa, breaking with earlier imagery, such as palm trees and surfboat crews. Barclays countered with a campaign featuring black children emulating professional adults, a representation of national development that remained colonial at heart. While these ads showed, at least to some extent, a growing understanding of local aspirations, they continued to address the same overseas investors who had formed their audience before independence.

The shift from colonial-style advertising to a postcolonial form that depended on themes of modernity and economic development was a gradual process. Old claims were retained while new features were introduced, creating several layers of meaning. The changes in advertising also reflected the reality that leading positions in politics and economic life were being filled by Africans. Political and commercial elites were initially the most important target audience as businesses sought acceptance, especially from African politicians. The development theme became prevalent in advertising, because it was the basis of interaction among British businessmen, colonial officials, and African politicians.

By 1970 advertising had adopted a noticeably more defensive tone 
as the positive role of business in development began to be disputed by experts, politicians, and the wider public. Companies tried to address some of the new issues of social costs, equality, and redistribution. However, Marxist views of dependency, in particular, offered little scope for corporate legitimacy. Ghana, as the smaller country, experimented with autarky policies for a few years but returned in 1983 to a neoliberal framework, implementing one of the first (and most successful) structural adjustment programs in Africa. Nigeria experienced an economic boom as a result of oil production and remained open to foreign investment, but it also initiated mandatory local participation in most enterprises and became notorious for corruption. In both countries, companies found that, over the long run, they could generally avoid loss of control (at the cost of entering into joint ventures with local interests) by continuing to cooperate with governments.

Although Charles Kennedy opened his 1992 article on the history of worldwide expropriations with the warning that the failure of structural adjustment programs might prompt a second wave of economic nationalism, this prophecy has not come to pass, at least so far. ${ }^{55} \mathrm{In}$ deed, the arguments put forth by British businesses in West Africa have endured into the new millennium, forming the basis of the United $\mathrm{Na}-$ tions' suggestions for good corporate citizenship:

There are rising expectations that TNCs [transnational companies] can contribute directly to the advance of development goals as one aspect of good corporate citizenship. Such firms are expected not only to abide by the laws of the host country, but also [to] pay greater attention to contributing to public revenues, creating and upgrading linkages with local enterprises, creating employment opportunities, raising skill levels and transferring technology.$^{6}$

Multinational companies still have to adapt their behavior to the expectations and demands of their respective host societies in order both to safeguard their property rights and to gain the goodwill of influential internal stakeholders. Making this adjustment is critical to their survival as businesses, because expropriations or general restrictions on foreign investment tend to occur in international and local climates in which corporate legitimacy is challenged, both economically and morally. Businesspeople in Africa have accepted this fact, as the following remark in the Economist makes clear:

\footnotetext{
55 Charles Kennedy, "Relations between Transnational Corporations and Governments in Host Countries: A Look into the Future," Transnational Corporations 1 (1992): 67-91.

${ }^{56}$ United Nations Conference on Trade and Development, World Investment Report 2003-FDI Policies for Development: National and International Perspectives (New York, 2003), 164.
} 
Don't even dream of doing business in Africa if you're not prepared to leave a visible legacy. ... Investing in communities is taken for granted. You do not get rewarded for doing it. You get punished for not doing it. ${ }^{57}$

A crucial fact to remember is that the development theme was not chosen single-handedly by business but was adopted to reflect host countries' expectations, and it depended on policies that were deemed appropriate by local stakeholders.

${ }^{57}$ Vincent Maphai, head of BHP Billiton, South Africa, quoted in "Business in Africa: A Flicker of a Brighter Future," Economist, 7 Sept. 2006, 81. 


\section{Contributors}

Gareth Austin teaches African and comparative economic history in the Department of Economic History at the London School of Economics and Political Science. He was trained in Cambridge and Birmingham universities, and he taught at the University of Ghana in the 1980 s before moving to London. A former editor of the Journal of African History, his most important work is Labour, Land and Capital in Ghana: From Slavery to Free Labour in Asante, 1807-1956 (2005). He is currently writing a book on markets and states, in the context of information and incentive problems, in West African history.

Stephanie Decker has just completed an ESRC postdoctoral research fellowship at the London School of Economics in the Department of Economic History and will be the Harvard Newcomen Fellow at Harvard Business School for the academic year 2007-08. Currently she lectures on international business at the University of Liverpool Management School. Her Ph.D. thesis, "British Business, Development \& Economic Nationalism in Ghana and Nigeria," was completed in 2006. Previously she published an article on Barclays Bank's Africanization program in Nigeria in the Journal of Imperial and Commonwealth History. Her research interests are the history of multinationals and the threat of economic nationalism in less developed countries in the 1960 s and 1970s, and the intersection of business architecture and symbolic corporate communications in West Africa.

Lynn Hollen Lees is professor of history at the University of Pennsylvania and codirector of the Joseph Lauder Institute of Management and International Studies. She has held visiting appointments at Katholieke Universiteit Leuven and University College London. Recent publications include The Solidarities of Strangers: The English Poor Laws and the People, 1700-1948 (Cambridge, U.K., 1998), and Global Society: The World since 1900 (Boston, 2003), written with Pamela K. Crossley and John W. Servos. She recently completed, with Andrew Lees, Cities and the Making of Modern Europe, 1750-1914. Her current research centers on the development of a multicultural colonial society in British Malaya during the nineteenth and twentieth centuries.

Robert L. Tignor is the Rosengarten Professor of Modern and Contemporary History at Princeton University, where he teaches courses on African history and world history. For many years, he was chair of the 